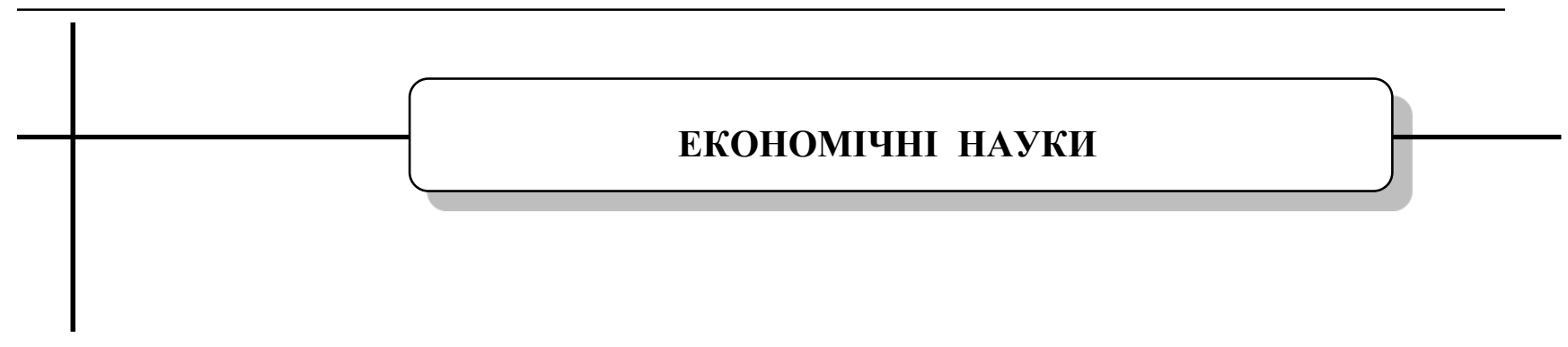

UDC 332.14 : 504.06

DOI: 10.15587/2313-8416.2018.129679

\title{
ECONOMIC MECHANISM OF REGIONAL ECOLOGICAL REGULATION
}

\author{
(C) K. Shurda
}

Статтю присвячено питанням екологічно спрямованого природокористування. Розглядаються проблеми економічного механізму регіонального екологічного регулювання економічної діяльності. Особливу увагу приділено змісту таких понять як охорона природи, екологічна безпека, екологічна ємність території регіону. Обговорюється екологічний аспект виробничої діяльності при розвитку досліджень у сфері екологізачії міст для забезпечення екологічної безпеки

Ключові слова: економічний механізм, раціональне природокористування, екологічне регулювання, екологічна безпека, екологізаџія міст

\section{Introduction}

The state of the natural environment is one of the most important parameters that determine the quality of life of the population. The preservation of the natural environment is turning into the main issue of human survival. The society needs to modify its livelihoods taking into account modern ecological requirements and opportunities for the reproduction of the natural environment. This is also an integral part of the sustainable development of society.

\section{Literature review}

The problem of solving the ecological-economic contradictions of nature exploitation through the development of the economic mechanism is multifaceted and stimulates ecologically directed nature exploitation. A complex study of this problem and its separate aspects is devoted to the scientific works of many scientists. In [1], the relationship between nature exploitation and the economy of the use natural resources and the economy of environmental protection is considered. Monographs [2] and [3] are branch scientific directions, which include protection of the air basin, clean air economy, marine economy, etc. The problems of the environment and industrial wastes from the point of view of the economics of nature management are the subject of monographic development [4]. Modern scientific approaches to the use and conservation of natural resources in the context of socio-economic development are considered in [5] and [6]. At the same time, the problem of the interrelation between economic development and ecological safety is considered from the point of view of elucidating the cause of ecological conflicts and the search for ways out of crisis (conflict) situations. However, despite a large number of scientific works on the problems of the economic mechanism nature exploitation and environmental protection and the provision of ecologically oriented economic activity of enterprises, a number of issues re- main controversial, for example, the definition of an economic mechanism for the ecological regulation of economic activity in the conditions of a particular region.

\section{The aim and objectives of the study}

The aim of research is analysis of the process of ensuring ecological and natural-technogenic security of the city, as a promising direction of research in the system of ensuring national security of the state.

To achieve this aim, the following tasks are necessary to solve:

1. to reveal the essence of concepts ecological safety and ecological capacity of the territory of the region;

2. to consider the ecological aspect of production activities;

3. to perform a critical analysis of the process of ecologiziation of cities as an important component of the state's ecological safety.

\section{Terminology of key concepts}

The concept of "nature protection" has long entered the minds of people. Almost two hundred years ago, Jean-Jacques Rousseau wrote that a human in his activities in many cases is harmful to the nature environment. But for the first time this term began to be widely used after the First International Congress on the Protection of Nature, which took place in 1913. Later, with the expansion of the scale and depth of the impact humanity on nature, together with the development of the movement for its protection, the content of the concept of "nature protection" also changed. Now there are such concepts as "nature protection", "environmental protection" and "nature environmental protection". Questions of terminology were considered at the First European Workshop on Environmental Education (Switzerland, 1971), which noted that the concept of "environmental protection" and "nature protection" are synonymous. 
From the considered terms it is necessary to give preference to the term "environmental protection", which has broader content features [7].

In the Law of Ukraine "On Environmental Protection" there is also the concept of "ecological safety", which is regarded as a state of protection the natural environment and vital human interests from the possible negative impact of economic and other activities, emergency situations of natural and technogenic character, their consequences [8]. Ecological safety is understood as a state of protection the vital interests of the individual, society, the nature environment from threats arising from natural and anthropogenic influences. Personality, the region, the state, the biosphere are subjects of ecological safety [9].

The state of the nature environment is one of the most important parameters determining the quality of life the population in the region. Ecological safety of the territory is an essential component of public security, therefore, regional authorities must produce and implement local ecological policies related to the state's ecological policy and aimed at protecting the nature environment from harmful technogenic impacts. Conducting an effective regional ecological policy positively affects the ecological situation throughout the state.

The transition to sustainable development of Ukraine is possible only if the sustainable development of all its regions is ensured, which implies the formation of an effective spatial structure of the country's economy in balancing the interests of all regions. At the same time, the problems to be solved in each region, to a large extent, should meet the national objectives, but taking into account local peculiarities.

The ecological capacity of the territory of the region is one of the most important characteristics of the ecological situation in the region. Ecological capacity in this case is understood as the ability of nature to overcome adverse effects and ensure the reproduction of natural systems existing in a given territory. At present, there is no single criterion for ecological capacity, but a system of criteria can be used that will allow to determine, although approximate, but realistic limits of the permissible aggregate anthropogenic load on specific territories. It should be noted that the assessment of the ecological capacity of the territory is the task of special research, and the application of the results is one of the most important elements regional ecological policy.

Sustainability of the region's economy development can be assessed using three groups of indicators: economic, social and ecological. Ecological indicators should ensure the integrity of biological and physical nature systems. Of particular importance is the viability of ecological systems on which the global stability of the entire biosphere depends.

\section{Results of the research}

The concept of "natural" systems and habitats relative to a specific region can be understood widely, including in them a man-made environment, such as, for example, a city. The main attention in such systems is paid to the preservation of the abilities for self-recovery and dynamic adaptation of these systems to changes, and not their preservation in some "ideal" static state. Meanwhile, degradation of natural resources and loss of biological diversity reduce the ability of ecological systems to self-repair [9]. So on the territory of the municipality, the state of the nature environment is one of the most important parameters that determining the quality of life the population. At the same time, the ecological aspect of production activity occupies a special place in the enterprises of the city-forming complex. The complexity of the process of municipal regulation in this complex is determined by the departmental affiliation of these enterprises and the opportunities for influence that are predominantly owned by state authorities [10].

Given the actualization of ecological components, there is a need to change the priorities of the activities municipal governments. Such ecological components include, for example, city transport. The developed countries have long appreciated the need for priority development of electric transport, which is reflected in a number of documents adopted by the governments of European countries. Special attention in these programs is aimed at reducing the negative impact of transport on the ecological condition of cities.

At the present time, the governments of leading Western countries are developing long-term strategic programs for the development of transport infrastructure of cities. In these programs, the priority is increase in the attractiveness of electric transport due to the expansion of the route network, the allocation of priority lanes, the introduction of real market relations between the customer of transport services and their executor.

The need for development and implementation of the program for development of the transport complex of Ukraine is clearly visible, taking into account the crisis situation in the cities and the similarity of the problem, which will clearly reflect the economic instruments for regulating the priority development of electric transport. For this, municipal regulation methods should be proposed that will allow to streamline the relationship between the customer of transport services and the contractor by applying settlement tariffs and non-traditional financing. Thus, it will be possible to create economic conditions for the development of an ecologically friendly type of city transport, which is electric transport.

In the process of research the economic mechanism of regional ecological regulation, special attention should be paid to ecologization of cities. The process of ecologization of cities was formed as a synthesis of scientific and practical knowledge that describe the interconnection of urban and natural systems. The beginning of the study of cities as the most important component of the state's ecological security was the work of Donnella Meadows "The Limits to Growth" (D. H. Meadows, the Roman Club) [11]. At this time, there was an oil crisis and, as a consequence, an economic crisis that forced the society of developed countries to rethink the priorities of their development [12]. In the development of research in the sphere of ecologization of cities, several periods should be distinguished (Table 1). 
Periods of development research in the sphere of ecologization of cities

\begin{tabular}{|c|c|}
\hline Period & Content \\
\hline $\begin{array}{l}\text { "Return to nature" } \\
\text { or "Ecoprogress" } \\
\quad(1970 \mathrm{~s}-80 \mathrm{~s})\end{array}$ & $\begin{array}{l}\text { Development of theoretical provisions on the eco-city (sustainable city) and ecological } \\
\text { housing, the emergence of eco-settlements in Ukraine at the beginning of the 1990s. Devel- } \\
\text { opment of cities on the basis of ecological architecture. The first United Nations declaration } \\
\text { on human settlements (Vancouver, 1976). Cities are understood as promising centers for } \\
\text { spreading the ideas of ecologization. }\end{array}$ \\
\hline $\begin{array}{l}\text { "The international co- } \\
\text { operation" } \\
\text { (1990-s to the present) }\end{array}$ & $\begin{array}{l}\text { High rates of spread scientific-technological progress, development of town-planning tech- } \\
\text { nologies that aimed at energy saving and water conservation, development of bio-cleaning } \\
\text { systems, etc. Particularly relevant issues of economic and regulatory legal nature of ensur- } \\
\text { ing ecological safety of cities. ISO- } 14000 \text { is introduced, which is a family of standards re- } \\
\text { lated to the environment and promotes organizations and businesses in the sphere of ecolo- } \\
\text { gization. International cooperation in the sphere of ecologization of cities (International } \\
\text { Conferences of Rio de Janeiro (1992) and Johannesburg (2002), the Istanbul Declaration } \\
\text { (1996) and the Declaration on Cities and Other Human Settlements in the New Millennium } \\
\text { (2001), United Nations Human Settlements Program (UN-Habitat). This period is charac- } \\
\text { terized by: } \\
\text { - the priority of the quality of the urban environment for humans and the reduction of an- } \\
\text { thropogenic load; } \\
\text { - introduction and development of methods ecological regulation in making management } \\
\text { decisions at the city level; } \\
\text { - the importance of maximum conservation of the ecosystem of cities in the process of their } \\
\text { development. } \\
\text { The Supreme Council of Ukraine adopted a number of laws and regulations to ensure } \\
\text { ecological safety: approved the Concept of Sustainable Human Settlements Development } \\
\text { (1999), which is "the basis for the development of regulations, programs and projects for } \\
\text { regulating planning and development, stimulating investment activities, improvement of } \\
\text { the tax policy, filling and rational use of local budgets for ensuring social-economic de- } \\
\text { velopment of settlements "; The Law of Ukraine "On the Protection of Atmospheric Air" } \\
\text { (1992), etc. }\end{array}$ \\
\hline
\end{tabular}

In the future, the strengthening of integral processes under the influence of the scientific-technological progress of the twentieth century, as well as the intensification of social relations, will entail a rethinking of the development of city settlements as an integral system with the definition of its component, as one of the leading, the ecological component [13]. At the same time, the provision of ecological and natural-technogenic security of the city should be identified as a promising direction of research in the system of ensuring national security of the state, and also as an integral component of sustainable development society.

In Ukraine, the problem of ecological safety of cities should be considered through the prism of tasks, the solution of which is connected with the formation of an effective organizational-economic mechanism for ensuring sustainable development and proceeding from the policy of national interests and strategy designed to determine the main tasks and development priorities of settlements. As for the latter, the development and implementation of appropriate methodological and practical approaches is complicated because of the lack of knowledge in the legislative field of the concept of ecological safety and natural-technogenic security of cities.

Thus, the Law of Ukraine "On Environmental Protection" (Article 50) defines ecological safety as "... the state of the natural environment, which prevents the deterioration of the ecological situation and the emergence of a hazard to human health". And also notes that "... ecological safety is guaranteed to citizens of Ukraine by implementing a wide range of interrelated political, economic, technical, organizational, state-legal and other measures" [14].

At the same time, foreign scientists do not widely use the concept of "ecological safety", much more often they use the concepts "environmental safety", "environmental protection" and their separate components. Thus, according to the definition of the Organization for Economic Co-operation and Development (OECD), environmental protection is any activity aimed at preserving or restoring the natural environment by preventing emissions (discharges) of pollutants into the environment or reducing their presence in environmental objects [15]. It should be noted that the term "safety" is often used in relation to safety of life activity and is considered in the field of research natural disasters and technogenic threats (natural-technogenic security).

In modern scientific circles of Ukraine there is no single view on the category of "ecological safety", in connection with which there are significant differences. Thus, in the opinion of B. M. Danylyshyn, safety is a state of the subject, which means that the probability of undesirable changes in any of its qualities, parameters of the property belonging to it and its external environment is not high [16]. M. A. Leskov offers to consider safety a little more as a type of dynamic equilibrium, which is characteristic of complex systems and consists in maintaining essential parameters for the conservation of the system [17]. That is, the concept of "safety" is determined not only by the protection from external influ- 
ences, but also by the internal properties of the system, such as stability, reliability, equilibrium and other such properties protect the system from real and potential destabilizing processes. According to the conclusions of Z. V. Gerasimchuk and A. A. Oleksik [18], modern scientific views on the definition of ecological safety can be divided into four approaches: "anthropocentric", "anthropocentric and resource", "anthropocentric and biocentric" and "anthropocentric, resource and biocentric" approaches.

\section{Conclusions}

1. The article analyzes the evolution of the concept of "ecological safety", from the perspective of the economics of nature exploitation, and also reveals the essence of the concept "ecological capacity of the territory of the region". Differences in the use of these concepts in Ukraine and abroad are determined.

2. The author substantiates the development of the transport complex in the context of the ecological aspect of production activities, taking into account the fact that city transport belongs to the changing ecological compo- nents and occupies a special place in the enterprises of the city-forming complex.

3 . In the work a critical analysis of the process of ecologization of cities as the most important component of the state ecological safety is carried out. The periods of development of researches in sphere of ecologization of cities are considered.

Considering the above, ensuring the ecological safety of cities is a system of views, objectives, principles and priorities, as well as political, economic, legal, administrative, scientific, technical, sanitaryepidemiological and educational actions based on them aimed at creating an enabling environment and comfortable conditions for vital activity and reproduction of the population, protection of natural resources and biodiversity, prevention of technogenic accidents and catastrophes. The dissemination of these ideas in the system of the ecological component of the triad "economy-ecology-society" at the national level allows achieving sustainable development of the society.

\section{References}

1. Burkinskiy B. V., Kovaleva N. G. Ekonomicheskie problemy prirodopol'zovaniya [Economic problems of nature management]. Kyiv: Naukova dumka, 1995. 143 p.

2. Balatskiy O. F. Ekonomika chistogo vozduha [Economy of clean air]. Kyiv: Naukova dumka, 1979. 296 p.

3. Kryzhanovskiy R. A., Gromova E. N., Galushkina T. P. Morskaya ekonomika segodnya i zavtra [Maritime economics today and tomorrow]. Moscow: Nauka, 1991. $161 \mathrm{p}$.

4. Meleshkin M. T., Stepanov V. N. Promyshlennye othody i okruzhayushchaya sreda [Industrial wastes and the environment]. Kyiv: Naukova dumka, 1980. 161 p.

5. Bartov V. F., Sedov V. V. Kontseptsiya vzaimosvyazey ekonomiki i prirody [The concept of interrelations between economy and nature]. Moscow: Mysl', 1984. 32 p.

6. Ekonomika prirodopol'zovaniya [Economics of nature management]: uchebnik / L. Hens, L. Mel'nik, E. Bun (Eds.). Kyiv: Naukova dumka, 1998. 480 p.

7. Ofitsiynyi sait Derzhavnoho upravlinnia okhorony navkolyshnoho pryrodnoho seredovyshcha u Odeskiy oblasti [Official web site of the State Ownership of the Foreign Nature of the Nature Environment in the Odessa region]. URL: http://ecology.odessa.gov.ua/

8. Zakon Ukrainy «Pro okhoronu navkolyshnoho pryrodnoho seredovyshcha» [The Law of Ukraine "On the Protection of the Environment"] / V. S. Kovalskyi (Ed.) // Ekolohichne zakonodavstvo Ukrainy. Kyiv: Yurinkom Inter, 2001. P. 7-46.

9. Melnyk L. H. Ekolohichna ekonomika: pidruchnyk [Ecological Economics]. Sumy: VDT "Universytetska knyha", 2003. $348 \mathrm{p}$.

10. Khvesyk M. A., Horbach L. M., Kulakovskyi Yu. P. Ekonomiko-pravove rehuliuvannia pryrodokorystuvannia [Economic and legal regulation of nature use]: monohrafiya. Kyiv: Kondor, 2004. 524 p.

11. The Limits to Growth: A report for the Club of Rome's Project on the Predicament of Mankind / Meadows D. H., Meadows D. L., Randers J., Behrens W. W. New York: Universe Books, 1972. 205 p. doi: 10.1349/ddlp.1

12. In the Nature of Cities: Urban Political Ecology and the Politics of Urban Metabolism / M. Kaika, N. Heynen, E. Swyngedouw (Eds.). New York: Routledge, 2006. 288 p. doi: 10.4324/9780203027523

13. Fedorenko N. P. Ekologiya i ekonomika - evolyutsiya vzaimootnosheniy. Ot "ekonomii" prirody do "bol'shoy" ekologii [Ecology and economics - the evolution of relationships. From the "economy" of nature to the "big" ecology]. Filosofskie problemy global'noy ekologii. Moscow: Nauka, 1983. 329 p.

14. Zakon Ukrainy "Pro okhoronu navkolyshnoho seredovyshcha" [The Law of Ukraine "On Environmental Protection"]. Verkhovna Rada Ukrainy, 1991. No. 1264-XII. URL: http://zakon4.rada.gov.ua/laws/show/1264-12

15. Glossary of Statistical Terms // OECD. 2007. 863 p. URL: http://ec.europa.eu/eurostat/ramon/coded_files/OECD_ glossary_stat_terms.pdf

16. Danylyshyn B. M. Pryrodno-tekhnohenni katastrofy: problemy ekonomichnoho analizu ta upravlinnia [Naturaltechnogenic disasters: problems of economic analysis and management]. Kyiv: VVPSU, 2001. 260 p.

17. Leskov M. A. Gomeostaticheskie protsessy i teoriya bezopasnosti. Bezopasnost' [Homeostatic processes and safety theory] // Informatsionnyy sbornik Fonda natsional'noy i mezhdunarodnoy bezopasnosti. 1994. Issue 4. P. 66.

18. Herasymchuk Z. V. Ekolohichna bezpeka rehionu: diahnostyka ta mekhanizm zabezpechennia [Ecological safety of the region: diagnostics and mechanism of provision]: monohrafiya. Lutsk: Nastyria, 2007. 280 p.

Дата надходження рукопису 06.03.2018

Kseneya Shurda, Doctor of Economics, Senior Researcher, Leading Researcher, Ukrainian Scientific Center of Ecology of Sea, Frantsuzkyi blvd., 89, Odessa, Ukraine, 65009

E-mail: shurda@i.ua 